\title{
Microbial and fermentation profiles, losses and chemical composition of silages of buffel grass harvested at different cutting heights ${ }^{1}$
}

\section{Ricardo Martins Araujo Pinho², Edson Mauro Santos², Gleidson Giordano Pinto de Carvalho ${ }^{3}$, Ana Paula Gomes da Silva², Thiago Carvalho da Silva ${ }^{4}$, Fleming Sena Campos ${ }^{3}$, Carlos Henrique Oliveira Macedo ${ }^{2}$}

\footnotetext{
${ }^{1}$ Financed by Conselho Nacional de Desenvolvimento Científico e Tecnológico (CNPq).

${ }^{2}$ Departamento de Zootecnia, Universidade Federal da Paraíba, Areia, PB, Brasil.

${ }^{3}$ Departamento de Zootecnia, Universidade Federal da Bahia, Salvador, BA, Brasil.

${ }^{4}$ Departamento de Zootecnia, Universidade Federal de Viçosa, Viçosa, MG, Brasil.
}

\begin{abstract}
The present study evaluated the microbial population, fermentation profile, losses and dry matter recovery, and chemical composition of silages of buffel grass at different cutting heights. To evaluate the microbial fermentation dynamics, the treatments resulted from a $4 \times 5$ factorial combination consisting of 4 cutting heights and 5 fermentation periods, in a completely randomized design with three replications. The fermentation was evaluated at the end of 1, 3, 7, 15 and 30 days. The other characteristics of silages with 30 days were evaluated following a completely randomized design with four treatments, consisting of 4 cutting heights $(30,40,50$ and $60 \mathrm{~cm})$, and five replications. Fermentation period and cutting height effects and interaction between both factors were observed on the populations of lactic acid bacteria (LAB), enterobacteria and molds and yeasts. The peak of development of LAB populations was observed on the seventh day of fermentation for the heights of 40 and $50 \mathrm{~cm}$, with 8.25 and $8.30 \mathrm{log} \mathrm{cfu} / \mathrm{g}$, respectively. The $\mathrm{pH}$ values of silages ranged with different cutting heights, in which at the height of $50 \mathrm{~cm}$ the decrease was most pronounced. However, the $\mathrm{pH}$ values were similar between the cutting heights at the end of 30 days of fermentation. Quadratic relationship was observed between lactic acid concentrations and cutting heights. The crude protein content behaved linearly, initially showing $128.5 \mathrm{~g} / \mathrm{kg} \mathrm{DM}$ at $30 \mathrm{~cm}$, decreasing as the cutting heights increased. The neutral detergent fiber and ether extract contents increased linearly with the cutting heights. Based on microbial populations, fermentation, losses and chemical composition, it is recommended to harvest buffel grass for silage from $50 \mathrm{~cm}$ on.
\end{abstract}

Key Words: Cenchrus ciliaris, enterobacteria, lactic acid, microbiology, semiarid

\section{Introduction}

Animal production in the Brazilian semiarid is influenced by climatic factors, especially the irregular distribution of rainfall. Forage availability is not uniform throughout the year due to the lower production during the dry season, leading to food scarcity in this period. Therefore, it is necessary to use methods of forage conservation, keeping its nutritional value, in order to use it in the off season period. Among these processes, ensiling has shown an important role, especially because it makes it possible to preserve the forage moisture.

In search for species adapted to semiarid conditions, buffel grass (Cenchrus ciliaris) stands out due to its high capacity of biomass production in low rainfall condition. According to Medeiros \& Dubeux (2008), buffel grass is highly efficient in using water and therefore presents greater resistance to water deficit compared with other species cultivated in semiarid regions.
The grass cutting height directly influences the fermentation conditions that take place inside the silo, because the concentration of soluble carbohydrates, the dry matter (DM) contents and the microbial populations are altered as the age advances (Santos et al., 2011).

When in growth stages with adequate nutritional value, grasses present some unfavorable characteristics for ensilage such as low dry matter and soluble-carbohydrate contents. This may promote secondary fermentation, increasing the losses and production costs.

Therefore, the present study evaluates the microbial population, fermentation profile, dry matter loss and recovery, and chemical composition of silages of buffel grass at different cutting heights.

\section{Material and Methods}

The experiment was conducted at the Pendência Experimental Station, which belongs to Empresa Estadual 
de Pesquisa Agropecuária da Paraíba S.A - Emepa, located in Soledade/PB, Brazil, at the coordinates $7^{\circ} 8^{\prime} 18^{\prime \prime S}$ and $36^{\circ} 27^{\prime} 2$ "W Gr, with an altitude of $534 \mathrm{~m}$. According to the Köppen classification, the type of climate is Bsh, with a relative humidity of around $68 \%$, with average rainfall of $400 \mathrm{~mm}$ per year and drought during the most part of the year.

A buffel grass (Cenchrus ciliaris) pasture implanted in an area of Luvisol with medium texture and low organic matter content was utilized in this experiment. The soil has the following chemical attributes $(0-20 \mathrm{~cm}$ depth): $\mathrm{pH}$ in water $=6.7 ;$ phosphorus $=27.1 ;$ potassium $=142\left(\mathrm{mg} / \mathrm{dm}^{3}\right)$; exchangeable calcium $=5.45$, exchangeable magnesium $=$ 1.1 ; sum of bases $=7.26 ; \mathrm{H}^{+}+\mathrm{Al}^{+}=1.49 ; \mathrm{CEC}=8.75$ $\left(\mathrm{cmolc} / \mathrm{dm}^{3}\right)$, exchangeable aluminum $=0.0$; base saturation $=$ $82.28 \%$. The fertilizer was applied at the beginning of the experiment, when the grass was cut at $10 \mathrm{~cm}$ from the soil for standardization. Ammonium sulfate was applied as $50 \mathrm{~kg} / \mathrm{ha}$ of nitrogen $(\mathrm{N})$.

The grass was harvested at $30,40,50,60 \mathrm{~cm}$ of height, $10 \mathrm{~cm}$ from the soil, with the aid of a mower, and then processed in stationary grass chopper. A difference of $10 \mathrm{~cm}$ between the heights, from the height of $30 \mathrm{~cm}$ on, was determined using the compressed height, by the ruler-andtransparency method. From $60 \mathrm{~cm}$, there was no increase in the compressed height. Thus, the four previously mentioned heights were evaluated.

The total rain through the regrowth period of buffel grass (Figure 1) was $118.6 \mathrm{~mm}$.

Immediately after the harvest, the ensilage was performed in PVC tubes with $15 \mathrm{~cm}$ of diameter and $40 \mathrm{~cm}$ of height, provided with a Bunsen valve to exhaust the gas. The material was compressed with wood pestles, placing approximately $2 \mathrm{~kg}$ of fresh forage per silo. Before ensiling, a $300 \mathrm{~g}$ grass sample from each height was used to determine the dry matter (DM) and soluble carbohydrate

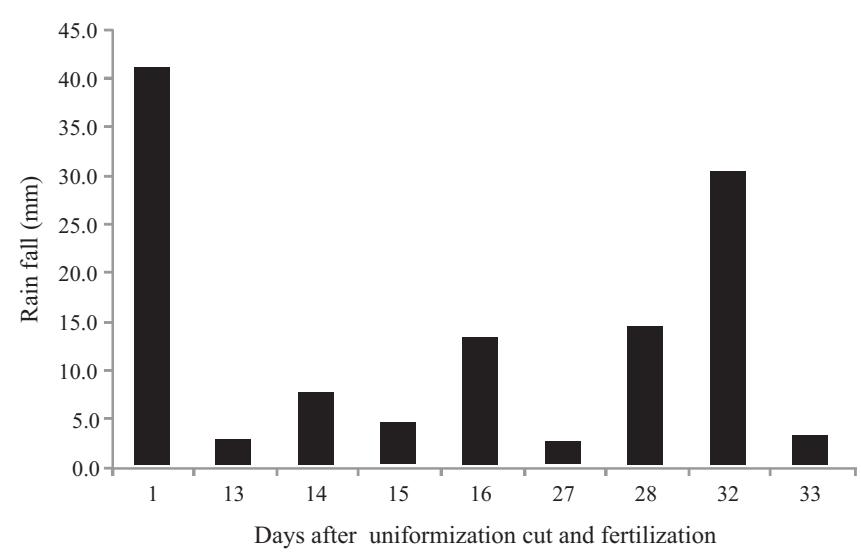

Figure 1 - Rainfall distribution during the experimental period. contents, according to Silva \& Queiroz (2002) and Deriaz et al. (1961).

To evaluate the microbiological and fermentation dynamics, the treatments resulted from a $4 \times 5$ factorial combination consisting of 4 cutting heights and five fermentation periods, in a completely randomized design with three replications. The fermentation was evaluated at the end of 1,3, 7, 15 and 30 days. The other characteristics of silages with 30 days were evaluated following a completely randomized design with four treatments, consisting of 4 cutting heights $(30,40,50$ and $60 \mathrm{~cm})$, and five replications.

The microbial group enumeration was performed from a $10 \mathrm{~g}$ sample of each replication per treatment in different stages of fermentation. The samples were taken from the central portion of the silo, discarding the upper and lower $5 \mathrm{~cm}$, and then $90 \mathrm{~mL}$ phosphate buffer were added to each sample, and homogenized in an industrial blender for 1 minute to obtain a $10^{-1}$ dilution. After that, successive dilutions were performed to obtain dilutions ranging from $10^{-2}$ to $10^{-9}$, since 30 and 300 colony forming units (cfu) are considered to be counted reliably. The plating was performed in duplicate in sterile Petri dishes.

The microbial populations were quantified using selective culture media for each microbial group:

Rogosa agar (Difco) for enumeration of lactic acid bacteria (LAB) after incubation for 48 hours in an environmental chamber at $39^{\circ} \mathrm{C}$; Brilhant green bile (Difco) for enumeration of Enterobacteria (ENT) after incubation for 24 hours in an environmental chamber at $30{ }^{\circ} \mathrm{C}$; and Potato Dextrose Agar supplemented with $1 \%$ tartaric acid at $10 \%$, after sterilization, for enumeration of yeasts and molds (YM) after incubation for 3-7 days at room temperature.

In each opening period, the upper and lower $5 \mathrm{~cm}$ of each silo were discarded and the central portion was then homogenized to take a $25 \mathrm{~g}$ sample of silage for $\mathrm{pH}$ determination, according to Bolsen et al. (1992). Twentyfive grams of silage were added to $100 \mathrm{~mL}$ of distilled water, left to rest for $1 \mathrm{~h}$, and then the $\mathrm{pH}$ was read using a potentiometer.

On the last opening day , 30 days after ensiling, gas and effluent losses, density, ammonia nitrogen $\left(\mathrm{NH}_{3}-\mathrm{N}\right)$, organic acids (lactic, acetic and butyric) and chemical composition were determined.

Twenty-five grams of silage were inserted in $200 \mathrm{~mL}$ of $0.2 \mathrm{M} \mathrm{H}_{2} \mathrm{SO}_{4}$, and left to rest in a refrigerator for $48 \mathrm{~h}$. After filtration on filter paper, the filtrate was frozen for subsequent determination of ammonia $\left(\mathrm{NH}_{3}-\mathrm{N}\right)$, according to Bolsen et al. (1992). For organic acid analysis, a $10 \mathrm{~g}$ sample was diluted in $90 \mathrm{~mL}$ of distilled water and filtered 
through a Whatman filter paper (Kung Jr. \& Ranjit, 2001). One milliliter of $20 \%$ metaphosphoric acid (w/v) was added to $2 \mathrm{~mL}$ of filtrate. The samples were centrifuged at 13,000 rpm for 15 minutes and then the analysis of organic acids (lactic acid - LA; acetic acid - AA; and butyric acid - BA) was performed in a high-performance liquid chromatograph (HPLC; Shimadzu) coupled to an ultra violet (UV) detector (SPD-10A VP) using $210 \mathrm{~nm}$ as wavelength, with a C-18 reverse phase column at $168 \mathrm{kgf}$ pressure and $1.5 \mathrm{~mL} /$ minute flow.

The losses of dry matter (DM) in the form of gas and effluent, and the dry matter recovery (DMR) were estimated according to the equations described by Zanine et al. (2010). The density was calculated through the ratio of quantity of fresh forage/volume of each silo.

To determine the silage chemical composition, a $300 \mathrm{~g}$ sample was collected from each silo. This material was predried in a forced ventilation oven at $60{ }^{\circ} \mathrm{C}$ until constant weight. After, the samples were ground in a knife mill with a $1 \mathrm{~mm}$ sieve and stored in plastic bottles. From these samples, dry matter (DM), crude protein $(\mathrm{CP})$, mineral matter (MM) and ether extract (EE) were determined, according to the methods described by Silva \& Queiroz (2002). The neutral detergent fiber (NDF) content was evaluated using a fiber analyzer (Ankom 220) with the detergent compositions recommended by Mertens (2002). The total carbohydrate (TC) content was calculated by the formula: $\mathrm{TC}=100-(\% \mathrm{CP}+\% \mathrm{EE}+\% \mathrm{MM})$, and nonfiber carbohydrates (NFC) through the formula: NFC = (\%TC - \%NDF), according to Mertens (1997).

The results were subjected to analysis of variance. The effects of cutting height and the opening day on the dynamics of microbial populations were evaluated by the Tukey test $(\alpha=0.05)$. To evaluate the $\mathrm{pH}$ as a function of fermentation period, the adjustment was made to the non-linear model $\mathrm{Y}=\mathrm{A}+\mathrm{B}$ and $\mathrm{x}^{\mathrm{ct}}$, proposed by Hristov \& McAllister (2002). The effect of cutting height on ammonia nitrogen, losses, density, organic acids and chemical composition was verified through linear regression analysis. The choice of regression equations was based on the determination coefficient and significance of regression coefficients, using the $t$ test $(\alpha=0.05)$. For all analyses, the SAEG (Sistema de Análises Estatísticas e Genéticas, version 8.1) program was used.

\section{Results and Discussion}

The dry matter content of buffel grass increased as the cutting height increased, with changes from 194.2 to $224.1 \mathrm{~g} / \mathrm{kg}$ for 30 and $60 \mathrm{~cm}$ heights, respectively (Table 1).
This increase in dry matter content was expected due to the advances in plant physiological maturity. However, it is important to highlight that these increases are of reduced amplitude compared with those observed for other tropical grasses. They are below the recommended values to mitigate undesirable fermentations and consequently losses in silage. The plausible reason for the slightly pronounced increase in the DM content may be a consequence of the rapid development of the grass, as well as the intense rainfall during the vegetative growth.

Based on the literature for tropical grasses, the DM content ranges from 157.8 to $280 \mathrm{~g} / \mathrm{kg}$ (Patrizi et al., 2004; Ribeiro et al., 2008; Ávila et al., 2009; Silva et al., 2011). According to McDonald et al. (1991), the optimum dry matter content for good quality silages ranges from 300 to $350 \mathrm{~g} / \mathrm{kg}$. On the other hand, it must be pointed that for tropical grasses, the reference values for this characteristic diverges from the recommendations of conventional statements such as that of McDonald et al. (1991), based on corn and sorghum plants. In addition, moisture absorbent additives can be used to increase the dry matter content up to values close to the ideal.

The average CHO content of the plant was $27.0 \mathrm{~g} / \mathrm{kg}$ (Table 1), varying from 23.8 to $31.0 \mathrm{~g} / \mathrm{kg}$ DM. Regarding the increase in the $\mathrm{CHO}$ contents with greater cutting heights, these values are considered to be low and characteristic of tropical grasses (Ribeiro et al., 2008; Ávila et al., 2009; Vasconcelos et al., 2009). However, the mean level of silage $\mathrm{CHO}$ was $7.2 \mathrm{~g} / \mathrm{kg}$, regardless of cutting height. The low content of $\mathrm{CHO}$ in the silage characterizes tropical grasses with better aerobic stability compared with maize and sorghum silages, presenting lower reserve of substrate for the growth of undesirable facultative aerobic microorganisms. Likewise, it is an indication that the soluble carbohydrates were used during the ensilage process, which may explain the development of lactic acid bacteria populations and the fermentation characteristics described in the following results.

There was effect of fermentation period, cutting height and interaction between both on LAB, ENT and MY (Table 2).

Table 1 - Average dry matter (DM) and soluble carbohydrate (CHO) contents of plant and buffel silage grass harvested at different cutting heights

\begin{tabular}{lccccc}
\hline & \multicolumn{4}{c}{ Cutting height } & CV \\
\cline { 2 - 5 } & 30 & 40 & 50 & 60 & $(\%)$ \\
\hline DM (g/kg NM) & 194.2 & 210.6 & 202.5 & 224.1 & - \\
Plant CHO (g/kg DM) & 23.8 & 25.4 & 27.9 & 31.0 & - \\
Silage CHO (g/kg DM) & 7.9 & 7.4 & 6.1 & 7.2 & 10.62 \\
\hline CV - coefficient of variation. & & & & &
\end{tabular}


The silage of buffel grass harvested at $30 \mathrm{~cm}$ presented smaller $(\mathrm{P}<0.05)$ LAB population irrespective of fermentation period, except on the thirtieth day of fermentation $(7.36 \mathrm{cfu} / \mathrm{g})$, which may be associated with high moisture content and lower soluble carbohydrates content (194.2 $\mathrm{g} / \mathrm{kg} \mathrm{DM}$ ). The peak development of LAB populations was observed on the third and on the seventh days of fermentation for the cutting heights from 40 (8.25 cfu/g) and on the seventh day of fermentation for the cutting heights from $50 \mathrm{~cm}(8.30 \mathrm{log} \mathrm{cfu} / \mathrm{g})$. The decrease in the microorganism population after this point is probably due to the reduced amount of carbohydrates for fermentation, which is a normal dynamics described in the literature for grass ensilage (Balsalobre et al., 2001; Santos et al., 2011).

Pereira et al. (2005) found that elephant grass plants had high initial concentrations of LAB (approximately $6 \mathrm{log} \mathrm{cfu} / \mathrm{g}$ ), also demonstrating that this group of bacteria became dominant over other groups in study. Nevertheless, all the LAB values are greater than $5 \mathrm{log} \mathrm{cfu} / \mathrm{g}$, the minimum established by Muck (1996) to ensure reduced losses during the ensilage process. The ENT showed peak development for 40 and $50 \mathrm{~cm}$ cutting heights on the third day of fermentation (5.11 and $5.72 \log \mathrm{cfu} / \mathrm{g}$ ). The lowest population $(\mathrm{P}<0.05)$ of this microbial group was observed in the cutting height of $60 \mathrm{~cm}$, regardless of fermentation period, averaging 3.63 and $2.52 \mathrm{log} \mathrm{cfu} / \mathrm{g}$ for the first and third days of fermentation, respectively. On the seventh and fifteenth days of fermentation, the ENT were only identified in buffelgrass silages harvested at 30 and $40 \mathrm{~cm}$.

Table 2 - Enumeration of lactic acid bacteria, enterobacteria and molds and yeasts in buffel grass silage with different cutting heights throughout the fermentation period (days)

\begin{tabular}{|c|c|c|c|c|c|c|}
\hline \multirow{2}{*}{$\begin{array}{l}\text { Height } \\
(\mathrm{cm})\end{array}$} & \multicolumn{5}{|c|}{ Fermentation period (days) } & \multirow{2}{*}{$\mathrm{CV}(\%)$} \\
\hline & 1 & 3 & 7 & 15 & 30 & \\
\hline & \multicolumn{5}{|c|}{ Lactic acid bacteria (log cfu/g forage) } & 4.31 \\
\hline 30 & $6.05 \mathrm{Bb}$ & 7.22Ba & 6.67Bab & $6.65 \mathrm{Bab}$ & 7.36Aa & \\
\hline 40 & 7.49Ab & $8.25 \mathrm{Aa}$ & $8.25 \mathrm{Aa}$ & $7.26 \mathrm{ABb}$ & 7.59Aab & \\
\hline 50 & 7.49Ab & $7.40 \mathrm{Bb}$ & 8.30Aa & $7.43 \mathrm{Ab}$ & 7.92Aab & \\
\hline \multirow[t]{2}{*}{60} & 7.18Aa & $7.40 \mathrm{Ba}$ & 7.88Aa & 7.39Aa & $7.78 \mathrm{Aa}$ & \\
\hline & \multicolumn{5}{|c|}{ Enterobacteria (log cfu/g forage) } & 11.29 \\
\hline 30 & $4.40 \mathrm{Bb}$ & $5.30 \mathrm{Aa}$ & $5.33 \mathrm{Aa}$ & $5.87 \mathrm{Aa}$ & ND & \\
\hline 40 & $4.36 \mathrm{Ba}$ & $5.11 \mathrm{Aa}$ & 4.67Aa & $4.82 \mathrm{Ba}$ & ND & \\
\hline 50 & 5.38Aa & $5.72 \mathrm{Aa}$ & ND & ND & ND & \\
\hline \multirow[t]{2}{*}{60} & $3.78 \mathrm{Ba}$ & $2.52 \mathrm{Bb}$ & ND & ND & ND & \\
\hline & \multicolumn{5}{|c|}{ Molds and yeasts (log cfu/g forage) } & 10.82 \\
\hline 30 & $4.95 \mathrm{Ba}$ & $4.48 \mathrm{Aa}$ & 4.34Aa & $2.88 \mathrm{Ab}$ & $3.17 \mathrm{Ab}$ & \\
\hline 40 & 8.11Aa & $2.61 \mathrm{Ba}$ & $2.50 \mathrm{Ba}$ & ND & ND & \\
\hline 50 & $3.45 \mathrm{Ca}$ & $2.99 \mathrm{Ba}$ & $2.84 \mathrm{Ba}$ & ND & ND & \\
\hline 60 & $3.63 \mathrm{Ca}$ & $2.81 \mathrm{Bb}$ & $2.36 \mathrm{Bb}$ & ND & ND & \\
\hline
\end{tabular}

Means followed by same uppercase letter in the column and lowercase letter in the row do not differ by the Tukey test $(\alpha=0.05)$.

$\mathrm{CV}$ - coefficient of variation; ND - not detected.
The disappearance of this microbial group can be associated with the further development of LAB.

According to Luiz \& Ramirez (1988), ENT usually multiply until approximately the seventh day of fermentation, when they are replaced by lactic groups. However, they can be found until the thirtieth day of fermentation because they have adaptations that enable their growth under anaerobic conditions and very low $\mathrm{pH}$. At the early fermentation stages, the ENT compete with LAB for the available soluble carbohydrates, and the competitive and antagonistic ability of LAB for an appropriate fermentation process is crucial. This behavior was observed in the grass ensiled with $30 \mathrm{~cm}$ cutting height, in which the ENT population reached 5.87 $\log \mathrm{cfu} / \mathrm{g}$ on the fifteenth day after ensiling. Santos et al. (2011) observed the disappearance of ENT in signal grass silages harvested at different ages only from the twentyeighth day after ensiling, which resulted in losses of more than $15 \%$ of total DM, regardless of regrowth age.

The growth dynamics of different microbial groups did not allow for any linear regression models to be adjusted, due to drastic changes after a certain time, allowing only to compare different cutting heights in each period of silo opening.

Mold and yeast populations were present and in greater number on the first day of fermentation, remaining present in all the periods of fermentation of grass cut at $30 \mathrm{~cm}$. For cutting heights of 40 and $50 \mathrm{~cm}$, this population remained constant up to seventh days. As for the cutting height of $60 \mathrm{~cm}$, on the third and seventh days, it was lower in relation to the first. From the seventh day of fermentation, MY were no longer identified in the silage, except for the cutting height of $30 \mathrm{~cm}$. Importantly, based on the silage $\mathrm{pH}$ values, the disappearance of these organisms was not expected, unlike what was observed by Pereira et al. (2005), in elephant grass silage, and by Santos et al. (2011), in signal grass silage. Probably, this disappearance is due to the reduced amounts of soluble carbohydrates in the silage, which may have inhibited the development of these microorganisms. This is especially relevant because it is an indicator that the silage will possibly have high aerobic stability, because it does not present molds and yeasts populations, as well as low levels of residual soluble carbohydrates (Table 1).

The results observed for the dynamics of microbial populations along with the fermentation parameters enables a more careful evaluation and better understanding of the ensilage process. Thus, the present study and other studies with tropical grasses (Santos et al., 2011; Pereira et al., 2007) have shown that the soluble carbohydrates present in plant tissue enable the development and predominance of $\mathrm{LAB}$, resulting in a quick decline of the $\mathrm{pH}$ values and consequent inhibition of undesirable microorganisms. 
The silage $\mathrm{pH}$ values ranged $(\mathrm{P}<0.05)$ with the different cutting heights (Figure 2). The decrease in the $\mathrm{pH}$ values for the $50 \mathrm{~cm}$ cutting height was the most pronounced; however, it matched the other cutting heights with 30 days of fermentation, except for $30 \mathrm{~cm}$, in which there was no fitting for any model. According to Santos et al. (2011), there is an increase in the soluble carbohydrate contents as the plant maturity progresses, resulting in increased microbial populations in the silage, which promotes decrease in $\mathrm{pH}$ values. The absence of a $\mathrm{pH}$ drop in the silage made with grass harvested at $30 \mathrm{~cm}$ indicates the occurrence of undesirable secondary fermentation, which is proven by the presence of ENT and MY 15 and 30 days after ensilage, respectively (Table 2 ).

Notwithstanding, $\mathrm{pH}$ values are above the ideal range considered by McDonald et al. (1991), which is 3.8 to 4.2, usually observed in corn or sorghum silages. However, for grasses, these values are acceptable and consistent with the values reported in the literature (Schocken-Iturrino et al., 2005; Pereira et al., 2007; Santos et al., 2011). In order to match the values found for corn silage, it would be necessary to use additives for absorbing moisture and/or sources of soluble carbohydrates, which would require further evaluation, especially in the aspects of costs and nutritional value.

There was a quadratic relationship for concentrations of lactic acid (LA) at the different cutting heights, with estimated maximum concentration of LA for the cutting height of $45.43 \mathrm{~cm}$ with a concentration of $29.6 \mathrm{~g} / \mathrm{kg}$ (Table 3). No models were fitted for production of acetic acid (AA) in relation to cutting heights, although the

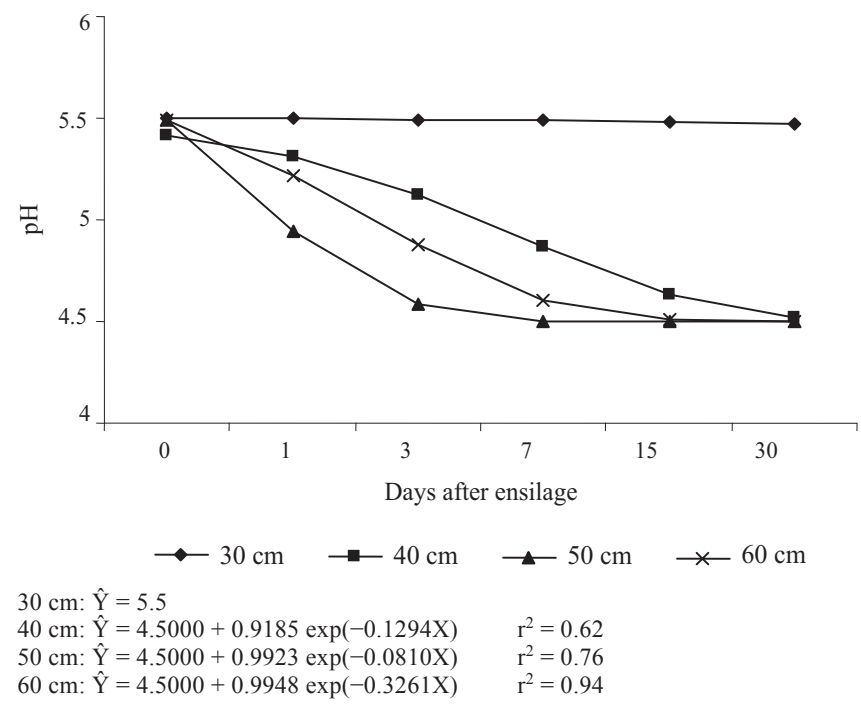

Figure 2 - pH values and regression equations of buffel grass silages at different cutting heights according to the opening periods. cutting height of $50 \mathrm{~cm}$ presented the lowest concentration of AA production. However, there was a linear decrease in the production of butyric acid (BA) as the cutting height was increased. Improvement in the fermentation profile in silages of tropical grasses as a function of maturity stage has been reported in the literature (Mari, 2002; Santos et al., 2011).

The concentration of ammonia nitrogen decreased quadratically. The quadratic behavior of the function is probably due to the reduction of crude protein contents with higher cutting heights (Table 4), since this variable is expressed as concentration of total nitrogen. Even for the lowest cutting heights, the values are below the minimum recommended by McDonald et al. (1991), which is $100 \mathrm{~g} / \mathrm{kg}$ of total nitrogen. Usually, values higher than $100 \mathrm{~g} / \mathrm{kg}$ of total nitrogen are reported for this variable in silages made from other tropical grasses harvested young, confirming the occurrence of reduced proteolysis in silage, which may be related to the disappearance of ENT populations, even for the cutting height of $30 \mathrm{~cm}$. Although not monitored, populations of clostridia, due to the greatly reduced concentrations of butyric acid, probably were ephemeral in the ensiling process, which may also have contributed to the reduced proteolysis and low concentrations of ammonia nitrogen.

The buffel grass reaches ideal fermentation profile quickly, due to its rapid regrowth, which can prevent sharp reduction in nutritional value. The buffel grass reached its greatest cutting height at 28 days of regrowth, while for signalgrass, Santos et al. (2011) observed growth up to 70 days of regrowth, with a sharp drop in nutritive value, especially in the protein content.

Dry matter increased linearly $(\mathrm{P}<0.05)$ along with the cutting heights (Table 4). Reis et al. (1997) stated that progress in the phenological stage increases the DM accumulation and reduces the nutritional quality, providing

Table 3 - Mean values and regression equations for concentration of ammonia nitrogen $\left(\mathrm{N}-\mathrm{NH}_{3}\right)$ and lactic (LA), acetic (AA) and butyric (BA) acids of buffel grass silages harvested at different cutting heights

\begin{tabular}{|c|c|c|c|c|c|}
\hline & \multicolumn{4}{|c|}{ Cutting height } & \multirow{2}{*}{$\begin{array}{l}\mathrm{CV} \\
(\%)\end{array}$} \\
\hline & 30 & 40 & 50 & 60 & \\
\hline $\mathrm{N}-\mathrm{NH}_{3}(\mathrm{~g} / \mathrm{kg} \mathrm{TN})$ & 70.9 & 35.8 & 48 & 50.8 & 17.01 \\
\hline $\mathrm{LA}(\mathrm{g} / \mathrm{kg} \mathrm{DM})$ & 23.8 & 26.7 & 28.3 & 21.7 & 12.30 \\
\hline AA (g/kg DM) & 11.4 & 14.0 & 9.3 & 16.5 & 20.44 \\
\hline \multirow[t]{2}{*}{$\mathrm{BA}(\mathrm{g} / \mathrm{kg} \mathrm{DM})$} & 1.8 & 1.8 & 1.6 & 1.4 & 24.98 \\
\hline & \multicolumn{4}{|c|}{ Regression equations } & $r^{2}$ \\
\hline N-NH3 (g/kg TN) & \multirow{4}{*}{\multicolumn{4}{|c|}{$\begin{array}{c}\hat{Y}=252.954-9.004 X+0.095 * X^{2} \\
\hat{Y}=-17.885+2.090 X-0.023 * X^{2} \\
\hat{Y}=12.835 \\
\hat{Y}=2.284-0.013 * X\end{array}$}} & 0.75 \\
\hline 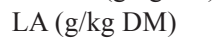 & & & & & 0.90 \\
\hline AA (g/kg DM) & & & & & \\
\hline BA (g/kg DM) & & & & & 0.89 \\
\hline
\end{tabular}


increased cell wall indigestible content. However, the range of variation was low, probably due to the rapid growth of the grass, which resulted in high effluent production as seen previously. This fact should be taken into consideration in the management of grass for silage. Regardless of the reasonable fermentation profile, perhaps it would be necessary to use absorbing moisture additives in order to offset the high moisture content, even for the greater cutting heights.

The crude protein contents behaved linearly $(\mathrm{P}<0.05)$, initially showing $128.5 \mathrm{~g} / \mathrm{kg}$ DM for the cutting height of $30 \mathrm{~cm}$, decreasing the values according to the increased cutting height and reaching $113.5 \mathrm{~g} / \mathrm{kg} \mathrm{DM}$ for the cutting height of $60 \mathrm{~cm}$. The results obtained herein are in agreement with the normal range for forage grasses, in which there is a progress in the cell wall lignifications as the plant matures, resulting in decrease in the CP contents. However, these values are higher than those found for other grasses (Hoveland \& Monson, 1994), which is probably due to the rapid development of buffel grass after cutting close to the ground, and nitrogen fertilization, which results in silage with high nutritional value, and less need for supplemental protein sources.

Mineral matter decreased linearly $(\mathrm{P}<0.05)$, as a result of the availability of minerals from mineral fertilizers applied at the beginning of the experiment; ammonium sulfate increased the solubilization and displacement of mineral nutrients to the buffel grass.

The NDF and EE contents increased linearly $(\mathrm{P}<0.05)$ with the cutting height, but with a very narrow increase range

Table 4 - Mean contents and regression equations of chemical components of buffel grass silages harvested at different cutting heights

\begin{tabular}{|c|c|c|c|c|c|}
\hline & \multicolumn{4}{|c|}{ Cutting height } & \multirow{2}{*}{$\begin{array}{l}\mathrm{CV} \\
(\%)\end{array}$} \\
\hline & 30 & 40 & 50 & 60 & \\
\hline $\mathrm{DM}(\mathrm{g} / \mathrm{kg})$ & 194.2 & 210.6 & 202.5 & 224.1 & 11.23 \\
\hline $\mathrm{CP}(\mathrm{g} / \mathrm{kg})$ & 128.5 & 123.5 & 118.5 & 113.5 & 8.37 \\
\hline $\mathrm{EE}(\mathrm{g} / \mathrm{kg})$ & 41.8 & 46.6 & 51.3 & 56.1 & 16.74 \\
\hline $\mathrm{NDF}(\mathrm{g} / \mathrm{kg})$ & 642.3 & 646.6 & 650.9 & 655.1 & 3.51 \\
\hline $\mathrm{OM}(\mathrm{g} / \mathrm{kg})$ & 850.4 & 857.1 & 863.8 & 870.5 & 0.75 \\
\hline $\mathrm{MM}(\mathrm{g} / \mathrm{kg})$ & 149.5 & 142.8 & 136.1 & 129.4 & 4.65 \\
\hline \multirow[t]{2}{*}{$\mathrm{NFC}(\mathrm{g} / \mathrm{kg})$} & 37.6 & 40.3 & 42.9 & 45.6 & 41.81 \\
\hline & \multicolumn{4}{|c|}{ Regression equations } & $r^{2}$ \\
\hline $\mathrm{DM}(\mathrm{g} / \mathrm{kg})$ & \multicolumn{4}{|c|}{$\hat{Y}=151.308+0.786 X$} & 0.70 \\
\hline $\mathrm{CP}(\mathrm{g} / \mathrm{kg})$ & \multicolumn{4}{|c|}{$\hat{\mathrm{Y}}=143.622-0.501 \mathrm{x}$} & 0.99 \\
\hline $\mathrm{EE}(\mathrm{g} / \mathrm{kg})$ & \multicolumn{4}{|c|}{$\hat{Y}=27.606+0.475 x$} & 0.87 \\
\hline $\mathrm{NDF}(\mathrm{g} / \mathrm{kg})$ & \multicolumn{4}{|c|}{$\hat{\mathrm{Y}}=629.550+0.427 \mathrm{x}$} & 0.91 \\
\hline $\mathrm{OM}(\mathrm{g} / \mathrm{kg})$ & \multicolumn{4}{|c|}{$\hat{\mathrm{Y}}=830.320+0.670 \mathrm{x}$} & 0.53 \\
\hline $\mathrm{MM}(\mathrm{g} / \mathrm{kg})$ & \multicolumn{4}{|c|}{$\hat{\mathrm{Y}}=169.68-0.67 \mathrm{x}$} & 0.60 \\
\hline $\mathrm{NFC}(\mathrm{g} / \mathrm{kg})$ & \multicolumn{4}{|c|}{$\hat{Y}=29.608+0.267 x$} & 0.76 \\
\hline
\end{tabular}

$\mathrm{CV}$ - coefficient of variation; $\mathrm{r}^{2}$ - determination coefficient.

$\mathrm{DM}$ - dry matter; CP - crude protein; EE - ether extract; NDF - neutral detergent fiber; $\mathrm{OM}$ - organic matter; MM - mineral matter; NFC - non-fibrous carbohydrates. for NDF, showing slight increase in the fibrous portion with cutting height, whose explanations can be the same for the small reduction in protein content, making it clear that the rapid buffel grass regrowth enables the maintenance of its chemical composition and, most likely, its nutritional value. This fact is relevant because a greater amount of grass can be harvested with increased cutting heights, resulting in lower costs per $\mathrm{kg}$ of silage produced. One may choose to harvest the grass with the greatest cutting heights, because little variation in the chemical composition can ensure maintenance of nutritional value, resulting in silages of lower costs with good nutritional value.

No models were fitted for DMR $(\mathrm{P}<0.05)$ according to cutting height (Table 5), but it was observed that from the $40 \mathrm{~cm}$ cutting height on, the DMR hardly changed, presenting much higher absolute values compared with those observed for $30 \mathrm{~cm}$. Quadratic behavior $(\mathrm{P}<0.05)$ was observed for gas losses as a function of cutting heights. The greatest gas losses, $112.1 \mathrm{~g} / \mathrm{kg} \mathrm{DM}$, was obtained with the $50 \mathrm{~cm}$ cutting height, and this loss may have occurred because the plant accumulated higher amount of soluble carbohydrates, which favored the $\mathrm{pH}$ below ideal values, fostering secondary fermentations.

The effluent losses decreased $(\mathrm{P}<0.05)$ with increasing cutting height. It was observed that the amount of effluent losses is changed according to the modification of plant dry matter content before ensilage, wherein the losses through effluents were inversely proportional to the plant dry matter content. Oliveira et al. (2010) observed that the volume of effluent produced in a silo is mainly influenced by the DM content of the ensiled forage. Although total losses of DM and fermentation profile did not change substantially after the height of $40 \mathrm{~cm}$, the linear reduction of effluent production should be taken into consideration when choosing the ideal height to harvest and ensile this grass.

Table 5 - Mean values of dry matter recovery (DMR), gas losses (GL) effluent losses (EL) and density of buffel grass silage with different cutting heights

\begin{tabular}{|c|c|c|c|c|c|}
\hline & \multicolumn{4}{|c|}{ Cutting height } & \multirow{2}{*}{$\begin{array}{l}C V \\
(\%)\end{array}$} \\
\hline & 30 & 40 & 50 & 60 & \\
\hline DMR (g/kg) & 850.3 & 950.7 & 945.4 & 944.8 & 2.66 \\
\hline GL (g/kg DM) & 89.8 & 62 & 112.1 & 53 & 60.32 \\
\hline $\mathrm{EL}\left(\mathrm{kg} / \mathrm{Mg}^{3} \mathrm{NM}\right)$ & 79.12 & 69.86 & 71.56 & 57.17 & 11.69 \\
\hline \multirow[t]{2}{*}{ Density $\left(\mathrm{kg} / \mathrm{m}^{3}\right)$} & 450 & 370 & 420 & 390 & 7.49 \\
\hline & \multicolumn{4}{|c|}{ Regression equations } & $r^{2}$ \\
\hline $\begin{array}{l}\text { DMR }(\mathrm{g} / \mathrm{kg}) \\
\text { GL }(\mathrm{g} / \mathrm{kg} \mathrm{DM})\end{array}$ & \multicolumn{5}{|c|}{$\hat{Y}=922.8$} \\
\hline $\mathrm{EL}(\mathrm{kg} / \mathrm{Mg} \mathrm{NM})$ & \multicolumn{4}{|c|}{$\hat{\mathrm{Y}}=98.2952-0.6414 * \mathrm{X}$} & 0.83 \\
\hline Density $\left(\mathrm{kg} / \mathrm{m}^{3}\right)$ & \multicolumn{4}{|c|}{$\hat{\mathrm{Y}}=407.50$} & \\
\hline
\end{tabular}

$\mathrm{CV}$ - coefficient of variation; $\mathrm{r}^{2}$ - determination coefficient; $\mathrm{Mg}$ - megagram. 
Regarding the compaction density, no behavior was observed according to cutting heights. However, higher value was verified at $30 \mathrm{~cm}$ when compared with the others. The density is changed according to the plant DM contents. The higher the DM content, the smaller the amount of compacted material per volume unit. Despite the density reduction, no increase was detected in the MY populations, indicating that it was not sufficient to compromise the silage compaction. However, under field conditions, it is important to watch the material compaction for the reduction in density not to compromise the compaction pressure, favoring the development of aerobic microorganisms inside the silo.

\section{Conclusions}

The reduced variation in chemical composition as well as in effluent losses and production costs may indicate that the best height for harvesting the buffel grass is $50 \mathrm{~cm}$.

\section{References}

ÁVILA, C.L.S.; PINTO, J.C.; FIGUEIREDO, H.C.P. et al. Estabilidade aeróbia de silagens de capim-mombaça tratadas com Lactobacillus buchneri. Revista Brasileira de Zootecnia, v.38, n.5, p.779-787, 2009.

BALSALOBRE, M.A.A.; NUSSIO, L.G.; MARTHA JUNIOR, G.B. Controle de perdas na produção de silagens de gramíneas tropicais. In: MATTOS, W.R.S.; FARIA, V.P.; SILVA, S.C. et al. (Eds.). A produção animal na visão dos brasileiros. Piracicaba: FEALQ, 2001. p.890-911.

BOLSEN, K.K.; LIN, C.; BRENT, C. R. et al. Effects silage additives on the microbial succession and fermentation process of alfalfa and corn silages. Journal of Dairy Science, v.75, n.11, p.3066-3083, 1992.

DERIAZ, R.E. Routine analysis of carbohydrate and lignin in herbage. Journal of Science Food and Agriculture, v.12, p.150-160, 1961

HOVELAND, C.S.; MONSON, W.G. Genetic and environmental effects on forage quality. In: HOVELAND, C.S. (Ed.) Crop quality, storage and utilization. Madison: ASAE, CCSA, SSSA, 1994. Cap.11, p.450-493.

HRISTOV, A.N.; McALLISTER, T.A. Effect of inoculants on wholecrop barley silage fermentation and dry matter disappearance in situ. Journal of Animal Science, v.80, p.510-516, 2002.

KUNG Jr., L.; RANJIT, N.K. The effect of Lactobacillus buchneri and other additives on the fermentation and aerobic stability of barley silage. Journal of Dairy Science, v.84, p.1149-1155, 2001.

LUIZ, L.; RAMIREZ, M. Evolución de la flora microbiana em ensilaje de king grass. Pastos y Forrajes, v.11, p.249-253, 1988.

MARI, L.J. Intervalo entre cortes em capim-Marandu (Brachiaria brizantha): Produção, valor nutritivo e perdas associadas à fermentação da silagem. 2002. 138f. Tese (Doutorado em Ciência Animal e Pastagens) - ESALQ/USP, Piracicaba.

McDONALD, P.J.; HENDERSON, A.R.; HERON, S.J.E. The biochemistry of silage. 2.ed. Mallow: Chalcombe, 1991. 340p.
MEDEIROS, H.R.; DUBEUX JUNIOR, J.C.B. Efeitos da fertilização com nitrogênio sobre a produção e eficiência do uso da água em capim buffel. Revista Caatinga, v.21, n.3, p.13-15, 2008.

MERTENS, D.R. Creating a system for meeting the fiber requirements of dairy cows. Journal of Dairy Science, v.80, p.1463-1481, 1997.

MERTENS, D.R. Gravimetric determination of amylase teated neutral detergent fiber in feeds with refluxing in beaker or crucibles: collaborative study. Journal of AOAC International, v.85, p1217-1240, 2002.

MUCK, R. Inoculant of silage and its effects on silage quality. In: INFORMATIONAL CONFERENCE WITH DAIRY AND FORAGE INDUSTRIES. Proceedings... US Dairy forage Research, 1996. p.43-52.

OLIVEIRA, L.B.; PIRES, A.J.V.; CARVALHO, G.G.P. et al. Perdas e valor nutritivo de silagens de milho, sorgo-sudão, sorgo forrageiro e girassol. Revista Brasileira de Zootecnia, v.39, n.1, p.61-67, 2010.

PATRIZI, W.L.; MADRUGA Jr., C.R.F. et al. Efeito de aditivos biológicos comerciais na silagem de capim-elefante (Pennisetum purpureum Schum). Arquivos Brasileiro Medicina Veterinária e Zootecnia, v.56, n.3, p. 392-397, 2004.

PEREIRA, O.G.; SOUSA, L.O.; PENTEADO, D.C.S. et al. Populações microbianas, $\mathrm{pH}$, relação nitrogênio amoniacal/Ntotal em silagens de capim-elfante com diferentes idades de rebrotação.. In: REUNIÃO ANUAL DA SOCIEDADE BRASILEIRA DE ZOOTECNIA, 45. 2005, Goiânia. Anais... Goiânia: SBZ, 2005. p.1-5.

PEREIRA, O.G.; ROCHA, K.D.; FERREIRA, C.L.L.F. Composição química, caracterização e quantificação da população de microrganismos em capim-elefante cv. Cameroon (Pennisetum purpureum, Schum.) e suas silagens. Revista Brasileira de Zootecnia, v.36, n.6, p.1742-1750, 2007.

REIS, R.A.; RODRIGUES, L.R.A.; PEREIRA, J.R.A.A Suplementação como estratégia de manejo de pastagem. In: SIMPÓSIO SOBRE MANEJO DA PASTAGEM, 13., 1997, Piracicaba. Anais... Piracicaba: Fundação de Estudos Agrários Luiz de Queiroz, 1997. p.123-150.

RIBEIRO, J.L.; NUSSIO, L.G.; MOURÃO, G.B. et al. Valor nutritivo de silagens de capim-Marandu submetidas ao efeito de umidade, inoculação bacteriana e estação do ano. Revista Brasileira de Zootecnia, v.37, n.7, p.1176-1184, 2008.

SANTOS, E.M.; PEREIRA, O.G.; GARCIA, R. et al. Microbial populations, fermentative profile and chemical composition of signalgrass silages at different regrowth ages. Revista Brasileira de Zootecnia, v.40, n.4, p.747-755, 2011.

SCHOCKEN-ITURRINO, R.P.; REIS, R.A.; COAN, R.M. et al. Alterações químicas e microbiológicas nas silagens de capimTifton 85 após a abertura dos silos. Revista Brasileira de Zootecnia, v.34, n.2, p.464-471, 2005.

SILVA, D.J.; QUEIROZ, A.C. Análises de alimentos (métodos químicos e biológicos). 3.ed. Viçosa, MG: UFV, Imprensa Universitária, 2002. 235p.

SILVA, T.C. DANTAS, P.A.S.; DÓREA, J.R.R. et al. Populações microbianas, perfil fermentativo e composição de silagens de capim-elefante com jaca. Archivos de Zootecnia, v.60, n.230, p.247-255, 2011.

VASCONCELOS, W.A.; SANTOS, E.M.; ZANINE, A.M. et al. Valor nutritivo de silagens de capim-mombaça (Panicum maximum Jacq.) colhido em função de idades de rebrotação. Revista Brasileira de Saúde e Produção Animal, v.10, n.4, p.874-884, 2009.

ZANINE, A.M.; SANTOS, E.M.; DÓREA, J.R.R. et al. Evaluation of elephant Grass silage with the addition of cassava scrapings. Revista Brasileira de Zootecnia, v.39, n.12, p.2611-2616, 2010. 